\title{
Breast Cancer cM1 TNM Finding v7
}

National Cancer Institute

\section{Source}

National Cancer Institute. Breast Cancer CM1 TNM Finding v7. NCI Thesaurus. Code C88374.

Breast cancer with distant detectable metastases as determined by classic clinical and radiographic means and/or histologically proven larger than $0.2 \mathrm{~mm}$. (from AJCC 7th Ed.) 